\title{
Insurance as a remedy against financial crisis
}

Citation for published version (APA):

Faure, M. G., \& Heine, K. (2014). Insurance as a remedy against financial crisis. Dovenschmidt Quarterly, 1, 35-41. https://doi.org/10.5553/DOQU/221199812014002001004

Document status and date:

Published: 01/01/2014

DOI:

10.5553/DOQU/221199812014002001004

Document Version:

Publisher's PDF, also known as Version of record

Document license:

Taverne

Please check the document version of this publication:

- A submitted manuscript is the version of the article upon submission and before peer-review. There can be important differences between the submitted version and the official published version of record.

People interested in the research are advised to contact the author for the final version of the publication, or visit the DOI to the publisher's website.

- The final author version and the galley proof are versions of the publication after peer review.

- The final published version features the final layout of the paper including the volume, issue and page numbers.

Link to publication

\footnotetext{
General rights rights.

- You may freely distribute the URL identifying the publication in the public portal. please follow below link for the End User Agreement:

www.umlib.nl/taverne-license

Take down policy

If you believe that this document breaches copyright please contact us at:

repository@maastrichtuniversity.nl

providing details and we will investigate your claim.
}

Copyright and moral rights for the publications made accessible in the public portal are retained by the authors and/or other copyright owners and it is a condition of accessing publications that users recognise and abide by the legal requirements associated with these

- Users may download and print one copy of any publication from the public portal for the purpose of private study or research.

- You may not further distribute the material or use it for any profit-making activity or commercial gain

If the publication is distributed under the terms of Article $25 \mathrm{fa}$ of the Dutch Copyright Act, indicated by the "Taverne" license above, 


\title{
Insurance as a Remedy against Financial Crisis
}

\author{
Michael Faure en Klaus Heine
}

\author{
Suggested citation \\ Michael Faure and Klaus Heine, 'Insurance as a Remedy against Financial \\ Crisis', (2014) The Dovenschmidt Quarterly
}

\section{Introduction}

The intervention of governments providing financial help has received a lot of attention due to the recent financial crisis. There has been a lot of academic debate on the 'bailing out' of financial institutions. ${ }^{1}$ Especially, the use of tax payers' money to support financial institutions has been controversially disputed as providing perverse incentives to investors and managers of financial institutions. Here it is not possible to summarize the whole debate, but it has become clear from the debate and the many examples of ad hoc intervention into financial markets that a more structural and more market-oriented approach to tackle with financial crises is needed. In this article, we would like to propose and to elaborate on such a vehicle that is inspired by insights from the insurance of large-scale natural disasters.

In many countries, governments generously intervene in all kinds of different forms to provide compensation to victims of a variety of natural or technological catastrophes. ${ }^{2}$ In some cases, ex post direct compensation is paid to victims; in other cases, the government acts as reinsurer of last resort (e.g. as far as terrorism is concerned) to deal with uninsurability of catastrophic risks.

We argue that, like in the case of natural disasters (or terrorism), a multilayered approach, including insurance and government intervention, may be a better solution than the various forms of bail-out of financial institutions as they occurred between 2007 and 2012. We aim to provide arguments of how such a multi-layered insurance system could work and how possible objections could be met. Of course, this article is only a step towards developing such an insurance solution; some issues regarding the practical implementation of our proposal may have to be addressed in further research. $\mathbf{3}$

The remainder of our article is set up as follows: first, it is simply asked the question why there would not be an insurance against financial crisis, and the conditions are sketched under which this would be feasible 
government intervenes, but to a relatively limited extent (Section 3 ). This leads us to a proposal for a structural multi-layered approach whereby insurance could play a role in case of financial crisis and the role of government would be reduced to the one of a reinsurer of last resort (Section 4). We end the contribution with a few concluding remarks (Section 5).

\section{The Problem and a Conditional Support}

\subsection{Bailing out Criticized}

After the financial crisis, financial institutions were on a large scale 'bailed out' by national governments via a variety of different techniques. This bailing out gave rise to substantial criticism in the literature, which can be summarized as follows: the injection of money into financial institutions took place on an ad hoc basis to avoid financial contagion and systemic risks of the financial sector. As a consequence, some financial institutions received financial support whereas others did not and went bankrupt. It were especially the larger financial institutions that benefited from state aid. 'Too big to fail' was often heard in that respect.

Notwithstanding the criticism that has been formulated on bail-outs, some form of government intervention in case of financial crisis may be unavoidable. It is related to the concept of a so-called systemic risk. This is referred to as the possibility that one firm's failure will result in large damages to the economy as a whole. ${ }^{4}$ To some extent a government intervention in case of financial crisis may therefore be unavoidable. The question, however, arises whether this government intervention in case of financial crisis should take the form of the current ad hoc bail-out or whether more structural solutions would not be more desirable. Would it theoretically be possible to insure against financial crisis? Corporations use insurance on a large scale, and the literature has indicated that the market conditions in which insurance operates provide an important tool to manage corporate risks. ${ }^{\mathbf{5}}$ However, several reasons can be advanced which would make insurance of a financial crisis difficult. A first problem that may arise is the predictability of the risk. Insurance is possible to the extent that risks remain predictable. ${ }^{6}$ It supposes that actuarially fair information is available on which the insurer can base his calculus of the likelihood that the insured event will occur. Factual and legal uncertainties may endanger this ex ante predictability. ${ }^{7}$ Financial crisis may for obvious reasons be problematic in that respect for the simple reason that reliable statistics to predict such a crisis may be lacking. This point is stressed, for example, by Acharya et ll $^{\mathbf{8}}$ who claim that the availability of reliable data and transparency was a major trigger of the recent financial crisis. Thus, a precondition for insurance of financial crises would be to create more transparency and making data available.

A second problem relates to the fact that the insured risk has to be exogenous in the sense that the insured himself cannot influence the risk. Endogeneity may be a serious problem ${ }^{\mathbf{9}}$ to the extent that it will usually not be the financial crisis as such that will be the subiect of insurance, 
as a result of the crisis. The risk of endogeneity will hence pop up, if it is impossible to determine whether business failure occurred as a result of the crisis or rather because of other causes. For that reason, traditionally it was held that the enterprise risk itself is in principle not insurable. The main reason advanced for refusing to insure the enterprise risk would be that this risk would not be predictable and hence an actuarially fair premium could not be calculated.

The main reason why insuring enterprise risk is considered problematic is of course linked to the well-known problems of moral hazard and adverse selection. Not only will insurance increase the demand for risky activities, but it will also be particularly attractive for those who need it most. That is of course precisely the problem of adverse selection, identified by Arrow. ${ }^{\mathbf{1 0}}$ The main problem both with moral hazard and with adverse selection is the information asymmetry between the insurer and the enterprise. ${ }^{\mathbf{1 1}}$ If insurers would not be able to distinguish whether the enterprise risk is exogenous (caused by a financial crisis) or endogenous (e.g. caused by mismanagement), incurable moral hazard would make the risk uninsurable.

The final reason why damage resulting from a financial crisis may not be insurable is simply that the damage resulting from a financial crisis may largely outweigh the possibilities of commercial insurers and even reinsurers. Hence, it might be argued that capacity is lacking to cover this type of catastrophic financial risk. ${ }^{\mathbf{1 2}}$

\subsection{A Conditional Support}

The problems identified in the previous section should by all means be taken seriously. There are, however, remedies available as a result of which they are not necessarily incurable.

Looking first at the issue of predictability, financial crises may technically be difficult to predict. However, the subprime mortgage crisis was certainly not the first global financial crisis. In addition, with the emergence of this crisis additional information has become available to make better estimates of the likelihood of future financial crises. Moreover, the literature has equally indicated that a lack of reliable statistics does not necessarily make a risk uninsurable. Kunreuther et al. ${ }^{\mathbf{1 3}}$ have argued that insurers can respond to this so-called 'insurer ambiguity' by charging a risk premium to account for the uncertainty following from the 'hard-to-predict' nature of an event.

The main issue is indeed the exogenous character of the risk. From the literature, various tools are known to remedy the moral hazard problem. ${ }^{\mathbf{1 4}}$ If moral hazard can be adequately controlled, the insured in fact behaves as if no insurance were available. The crucial question is hence, as also Von der Schulenburg noted, ${ }^{\mathbf{1 5}}$ whether more information can be made available to adequately control the moral hazard problem. As far as financial crisis is concerned, the key issue will of course be for insurers only to intervene when damage resulting from business failure was effectively caused by the financial crisis and not by causes which lay in the behaviour of the insured himself and hence could have been prevented (e.g. mismanagement). To the extent insurers invest in risk classification and risk management, they will also be able to obtain 
risk (financial crisis) or from an endogenous factor. ${ }^{\mathbf{1 6}}$

Probably the major problem still in the insurance of systemic risks generally may be the capacity issue. Although techniques such as pooling, co-insurance and reinsurance undoubtedly have increased the capacity of the traditional insurance market, ${ }^{\mathbf{1 7}}$ the traditional problem with the insurance of risks of a catastrophic nature is that traditional insurance markets may lack the capacity to deal with those catastrophic risks. ${ }^{\mathbf{1 8}}$ At this point, the question arises whether government could step in as a lender or reinsurer of last resort to support the functioning of insurance markets where they would otherwise (due to capacity problems) fail. We will now turn to a case where such a role for government already exists, being in insurance of catastrophes.

\section{Insurance for Catastrophes}

Many law and economics scholars favour insurance solutions for catastrophic risks especially when compared with the alternative of government-provided compensation. For example, Epstein ${ }^{\mathbf{1 9}}$ qualifies government intervention as a 'catastrophic response to catastrophic risk', meaning that it will dilute the incentives to develop insurance solutions. Also scholars as Priest, ${ }^{\mathbf{2 0}}$ Kaplow, ${ }^{\mathbf{2 1}}$ and Skees and Barnett ${ }^{\mathbf{2 2}}$ have pointed at the advantages of insurance in dealing with catastrophic risk: insurance better enables an adequate risk differentiation and risk spreading, and if insurance markets are competitive, insurers can be assumed to be better able to deal with classic insurance problems, such as moral hazard and adverse selection. A similar point has been made by Kunreuther, who already since 1968 argues in favour of insurance solutions for disasters. ${ }^{23}$

The argument in favour of government intervention is that, without government support, insurance coverage for disasters would simply not have developed. ${ }^{\mathbf{2 4}}$

Reinsurance by the state can then be considered as an adequate method to resolve the uninsurability problem. A condition is of course that the government charges an actuarially fair premium for its intervention. This type of government intervention has, moreover, the advantage that $e x$ post relief sponsored through the public purse can be avoided. Where the government acts as reinsurer, this at least has the advantage that a premium can be paid by those who actually cause or run the risk. It can thus facilitate market solutions, still provide incentives for prevention to potential victims and avoid a negative redistribution from tax payers to victims. Thus a state intervention as reinsurer may avoid the 'catastrophic responses to catastrophic risks'.25

Kunreuther and Michel-Kerjan ${ }^{\mathbf{2 6}}$ also argued in favour of this type of government-provided reinsurance. They argue that one advantage is that the government has the capacity to diversify the risks over the entire population and to spread past losses to future generations, thus creating a form of cross-time diversification which the private market could not achieve. On the other hand, they argue that, especially as far as terrorism is concerned, government participation in insurance programmes is crucial since the risk of terrorist attacks is partly in the government's control and the government can have more information on on-going 
Of course, it is not difficult to point at many differences between natural disasters or terrorism on the one hand and the financial crisis on the other. For example, the absolute economic impact of the financial crisis can be huge because of the worldwide interrelatedness of banks, issuers of securities and industry. Natural and technological disasters can have widespread severe damages as well, but the disasters are usually limited to a certain population and some foreseeability of the budget for compensating victims may be possible.

A second difference is that the causes of natural disasters or terrorism can usually be easily defined. In a financial crisis, it is not so easy to determine whether the economic failure of a firm traces back to the financial crisis or may be induced by general mismanagement. Hence the endogeneity of the risk may be a much more serious problem in case of a financial crisis.

Despite these problems, the case of catastrophes shows that a multilayered approach could also be applicable to the insurance of financial intermediaries whereby the advantages of insurance (with the possibilities of risk differentiation) are used to the full extent (thus providing incentives to the prevention of risks), when government only intervenes as reinsurer or lender of last resort to provide capacity where commercial (re)insurance markets would fail. ${ }^{\mathbf{2 8}}$

\section{Proposal}

\subsection{A Structural Approach}

First we would suggest dealing ex ante with the possibility of losses due to a financial crisis in a structural way rather than ad hoc and ex post. This aims (via insurance) at implementing market solutions for compensating victims of financial crisis. Hence, compensation will no longer be ad hoc, but structural.

Second, government intervention should be (like in the case of terrorism or natural catastrophes) limited to intervening there where private insurance markets fail due to lacking capacities. Hence, the government intervention will be limited and compensation will be partly paid by private insurance companies.

An apparent advantage of this structural approach is its pre-emptive effect on financial crises. Since insurance companies will have to permanently monitor insured companies, in order to make adequate risk assessments and to adapt insurance premiums, there will be a constant flow of information regarding a company's financial status, business model and management capacity. While yet 'due diligence' of companies takes place almost exclusively in the event of mergers or initial public offerings $^{\mathbf{2 9}}$ and it is also questionable whether regular audits by accounting firms make a proper assessment of a company's financial status, ${ }^{30}$ the engagement of insurance companies would be an additional safeguard for providing proper information on a company's financial status.

Of course, insurance markets alone may not have enough capacity to insure a financial crisis. But the comparison with natural disasters teaches that it is nossible to still use insurance but only un to the level 
system has to be introduced allowing government to intervene as a reinsurer of last resort for the large losses where insurance markets would miss capacity.

\subsection{A Multi-Layered Approach}

From the discussion of financial compensation for victims of catastrophes in Section 3, it could be learned that a multi-layered approach can be introduced whereby a first layer is typically born by the victims themselves. The second layer of losses is covered by private insurance companies and reinsurance. The third layer of losses is covered by the public budget whereby the government becomes a reinsurer of last resort. This model, so we propose, also has capacity to be applied to potential losses caused by a financial crisis. While it is not likely that the economic risks of a financial crisis can be fully insured by private insurers, because insurers are highly intertwined with financial markets and because of the sheer amount of funds that are needed, the introduction of private insurance can reduce the risk that the public spends subsidies to firms, which are in trouble even without financial crisis. More technically spoken, a multi-layered insurance programme can serve as a screening device that reduces the likelihood of granting non-eligible subsidies, when a public agency has to decide on a huge amount of applications for subsidies in a short time.

The first layer of a multi-layered insurance programme is typically the requirement that the insurance holder bears a part of the costs by himself. ${ }^{31}$ This is an incentive for firms not to engage in moral hazard, but it may also help to overcome adverse selection. For example, the requirement to hold enough equity to compensate temporary losses may be understood as a sort of obligation for firms to self-insure a part of the losses in the event of a financial crisis. Thus the here proposed first layer of insurance is similar to the minimum capital requirements laid down in the Basel Accords. But the here proposed self-insurance may deviate from the Basel capital requirements. Although the self-insurance of the first layer must not be lower than the Basel capital requirements, it may be higher in order to contract a lower premium with the insurer. Thus, the Basel Accords can be understood as an internationally recognized safeguard against financial instability of banks, while the requirement of self-insurance aims primarily at preventing moral hazard, when insurance against financial crises becomes possible.

At the second layer, private insurers offer risk-adjusted insurance contracts to firms, which will cover the risk of becoming illiquid and which will guarantee the maintenance of a firm's operations. Although in case of a severe financial crisis this private part of the financial safety net will often not be sufficient to rescue all firms, it will nevertheless contribute to financial stability. However, the most significant aspect of the second layer is that insurers will undertake investigations (e.g. due diligence and stress tests) in order to calculate the risk-adjusted premiums for firms. Moreover, an adequate monitoring by the insurer should also enable the insurer to predict whether his particular insured financial institution is more or less reliable and hence risk-adjusted premiums could be charged. Insurance comnanies could of course, also 
occurring, but also the potential losses, but that is precisely why a multilayered system is designed to keep the potential risk exposure of the insurer in the second layer limited. Once the amount exceeds the second layer, government will intervene.

The crucial issue is that the insurer engages in a careful monitoring of the insured financial institution. Even if an international and coherent public financial monitoring system would be in place, as for example suggested by the Larosiere-report (2009), a monitoring by insurance companies seems to be advantageous, or at least an important complement to public monitoring. The reason is that competition between insurance companies sets incentives for the insurers not only to make correct risk assessments, but also to further develop the assessment techniques. This means high-powered market incentives would trigger insurance companies to make correct risk assessments, thereby employing cut-edge technologies to correctly assess the risk. This is again supported by experiences with large natural disasters, where reinsurers not only have fairly good statistical models to assess the risk, but also can recommend the insured how to better protect against the risk.

At the third layer, the public steps in as a 're-insurer of last resort' and may grant subsidies. While at the second layer private insurance companies can only diversify risk horizontally between actual firms of a risk pool, government can diversify the risks over the entire population of firms and spread past losses to future taxpayers, which is a sort of cross-time diversification of risk that private insurance markets cannot achieve. ${ }^{32}$ Because of the information that is generated by private insurance firms on the second layer and the signals that are freely given by firms on the first layer, public agencies can make timely decisions on subsidies with a considerably reduced failure rate.

\subsection{Specific Aspects}

A first aspect concerns the question for whom this multi-layered framework should be provided as a protection against financial crisis. Theoretically, the system could be applicable both to financial intermediaries and to companies in the real economy. However, the bailing out (for which we precisely want to present an alternative) especially took place as far as financial intermediaries are concerned. When referring to financial institutions, the first target of our system is obviously banks, including both retail and investment banks. The policy maker could envisage enlarging the system to include others as well in the system, such as investment companies. An important reason for including those as well is that the failure of those investment companies could also have a systemic nature, which is precisely the reason to start the system in the first place.

A second issue is how one distinguishes whether losses are caused by a financial crisis. This problem is as such not new. It also appears in the insurance of natural catastrophes where, for example, in France specific insurance coverage is only provided when damage is caused by a natural catastrophe. Hence, in France it has to be determined whether an event can be classified as a natural catastronhe. Likewise in our case, it will 
financial crisis, as a result of which the proposed system will be triggered. The example of France shows that the government will take an administrative decision declaring a particular event a natural catastrophe. ${ }^{33}$ A similar system could thus be used in our model: government could declare a particular stressful financial situation 'a financial crisis' as a result of which the multi-layered approach will be triggered. In addition, there could be arguments for shifting the decision on declaring an event a financial crisis to an independent party, in order to avoid political interference. One may consider the central bank playing a crucial role or a financial supervisory authority.

With regard to the fact that a financial crisis might not occur spontaneously like an earthquake, but may be triggered in the beginning by small events that are not identified as crisis symptoms, the proposed insurance approach is advantageous. This is because insurers have to examine in regular intervals the financial status and business model of banks, in order to adjust premiums. In addition, banks could nominate compliance officers, who are in charge to correctly report financial figures to the insurers. It can be expected that through these investigations financial risks become earlier detected and countermeasures can timely be launched.

A third and complicated issue is whether a multi-layered coverage system for financial crisis should be made mandatory. Here the parallel with natural catastrophes may not be that obvious. In the case of natural catastrophes, the system is often made mandatory (like in France and in Belgium). The arguments supporting compulsory insurance for natural disasters are that potential victims largely underestimate risks. ${ }^{\mathbf{3 4}}$ However, these behavioural arguments based on limited information and bounded rationality, which support mandatory insurance in the case of natural catastrophes, may not apply in the case of financial intermediaries. There is obviously a major difference between mandatory insurance for disasters on the one hand and insurance for financial crisis on the other. Disaster insurance is focused on problems of civilians who may lose their houses and employment opportunities when their houses (or employer's businesses) are destroyed in an earthquake or a flood. The story is a different one when considering insurance by financial institutions against a financial crisis. Much of the benefit of the insurance is for shareholders or bondholders of the financial institutions, who are already protected by deposit-guarantee schemes. That may make the argument for mandatory insurance much stronger in case of natural disasters than in case of financial crisis. As a starting point, the system should therefore be voluntary. This implies that a separating equilibrium is created to distinguish between the good and the bad risks. Those who would not seek insurance coverage (presumably the bad risks) would then also not be bailed out, in order to preserve the credibility of the system.

The problem is, however, that the starting point to create the system in the first place was that financial risks are systemic. In other words, destabilization of one financial intermediary (like Lehman Brothers) could lead to the destabilization of the entire economy. If the system is supposed to prevent these kinds of systemic risks, there may be an argument in making it mandatory. Indeed, if the scheme were merely 
'too big to fail' would have no incentives to purchase insurance because in case of a crisis, they would be counting on government support. Mandatory insurance may address this problem. However, this may create the problem that there could be a pooling equilibrium in which it is no longer possible to distinguish between good and bad risks. Moreover, a system of mandatory insurance often leads to a crosssubsidisation whereby good risks finance bad risks. 35 The question therefore arises whether it is possible, even under mandatory insurance, to attain a separating equilibrium, in other words, distinguishing between good and bad risks. Again, the example of natural catastrophes may be instructive. For example, in Belgium there is mandatory insurance against flooding, included in the fire insurance. However, premiums are not fixed and can hence be differentiated. Thus good risks (e.g. protecting themselves with preventive measures against flooding) can, even in a mandatory insurance system, still be rewarded as a result of risk differentiation.

A fourth issue is that our model, of course, assumes that the insurer will play an important role in the second layer as financial risk manager by differentiating risks and thus controlling moral hazard. A particular problem that may arise is that insurance companies themselves can also be part of larger financial institutions, which may inhibit their independence in judging the financial performance of institutions with which they may have financial linkages. In those cases, guarantees need to be provided concerning the independent assessment by the insurance company. Some private insurance companies may be underestimating financial risks themselves, like apparently the large US-based insurer AIG did. Insurance companies therefore have to rely on independent third-party opinion and expertise when performing their monitoring task. The key element in our model is indeed that insurers will, being exposed to risk, have incentives to adequately monitor the performance of financial institutions. This, of course, supposes a sufficient independence from the financial institutions that they insure and hence have to monitor ('Chinese walls').

A final issue might be that one could argue that the premiums would be so high that an effective insurance against systemic risk would practically not be possible. One may argue that the sheer amount of money needed cannot be provided by insurance. This must not be the case, because there would always be the government with its possibility of cross-time diversification of risk. But there are also examples, where in the aftermath of the financial crisis of 2007 countries started to build-up a sort of insurance for large financial intermediaries. For example, in 2011 in Germany a bank levy became effective. Banks and other financial intermediaries have to pay up into a fund, which is meant to stabilize the banking sector in case of a financial crisis. The levy is according to the systemic relevance of the bank and the financial risk of the bank. ${ }^{\mathbf{6}}$

\section{Concluding Remarks}

In this contribution, insights are transferred from the theory and practice of insuring technological and natural disasters to the idea of insuring the financial risk of financial intermediaries in case of a financial crisis. 
from financial crises in many respects, it is striking that both events have similar features in regard to the problems that an adequate insurance for both risks has to overcome.

Notwithstanding our optimistic stance, we are aware that our proposal is only a first step on the way to an insurance approach towards the avoidance and management of financial crises. One of the crucial questions is clearly how insurance companies can actually act as financial risk managers and which instruments they can employ to control financial institutions; another issue is how the system would precisely work if a financial crisis would occur, i.e. how the decision to compensate would be taken and what amounts would precisely be compensated. This is clearly also related to the possible interaction between the three layers whereby a central issue remains how the institutional framework can be shaped to provide adequate incentives to all stakeholders involved in the three layers. It clearly went beyond the scope of this article to address those issues in detail. Working out how insurance for financial crises may work concretely will be the subject of further research.

Bibliography

V. Acharya, T. Philippon, M. Richardson \& N. Roubini, "The Financial Crisis of 2007-2009: Causes and Remedies”, 18 Financial Markets, Institutions \& Instruments 2009, pp. 89-137.

G. Akerlof, “The Market for 'Lemons': Quality, Uncertainty and the Market Mechanism”, 84 Quarterly Journal of Economics 1970, pp. 488500.

I. Anabtawi \& S.L. Schwarcz, "Regulating Systemic Risk. Towards an Analytical Framework". Available at:

<http://papers.ssrn.com/sol3/papers.cfm?abstract_id=1670017>.

K. Arrow, "Uncertainty and the Welfare Economics of Medical Care", 53 American Economic Review 1963, pp. 941-973.

K.J. Crocker \& A. Snow, “The Theory of Risk Classification”, in G. Dionne (Ed.), Handbook of Insurance, Boston, Kluwer Academic Publishers 2000, pp. 245-276.

J. Danielsson, “On the Feasibility of Risk-Based Regulation”, 49 CESifo Economic Studies 2003, pp. 157-179.

J. Danielsson \& H.S. Shin, "Endogenous Risk”, London School of Economics, Working Paper, 2002.

K. Dowd, "Moral Hazard and the Financial Crisis", 29 Cato Journal 2009, pp. 141-166.

R. Epstein, “Catastrophic Responses to Catastrophic Risks”, 12 Journal of Risk and Uncertainty 1996, pp. 287-308. 
M. Faure, "Financial Compensation for Victims of Catastrophes: A Law and Economics Perspective", 29 Law \& Policy 2007, pp. 339-367.

M.G. Faure \& T. Hartlief, Insurance and Expanding Systemic Risks, Paris, OECD 2003.

M.G. Faure \& T. Hartlief (eds), Financial Compensation for Victims of Catastrophes, A Comparative Legal Approach, Vienna, Springer 2006.

M.G. Faure \& K. Heine, "Can European State Aid Control Learn From the Management of Disastrous Crises?”, in T. Theurl (Ed.), Institutionelle Hintergruende von Krisen, Berlin, Duncker und Humblot 2011, pp. 97125 .

M.G. Faure \& K. Heine, "Insurance Against Financial Crises?”, 8(1) NYU Journal of Law and Business 2012, pp. 117-150.

M.G. Faure \& K. Heine, "An Insurance Approach for Preventing Financial Crisis”, in J.R. LaBrosse, R. Olivares-Caminal \& D. Singh (eds.), Financial Crisis Containment and Government Guarantees, Cheltenham, Edward Elgar 2013, pp. 174-188.

K.A. Froot, The Financing of Catastrophe Risk, Chicago, IL, The University of Chicago Press 1999.

S.E. Harrington, "Rethinking Disaster Policy", 23 Regulation 2000, pp. 40-46.

L. Kaplow, "Incentives and Government Relief for Risk", 4 Journal of Risk and Uncertainty 1991, pp. 167-175.

H. Kunreuther, "The Case for Comprehensive Disaster Insurance", 11 Journal of Law and Economics 1968, pp. 133-163.

H. Kunreuther, "Mitigating Disaster Losses Through Insurance”, 12 Journal of Risk and Uncertainty 1996, pp. 171-187.

H. Kunreuther \& E. Michel-Kerjan, "Challenges for Terrorism Risk Insurance in the United States”, 18 Journal of Economic Perspectives 2004, pp. 201-214.

H. Kunreuther \& E. Michel-Kerjan, "Insurability of (Mega-) Terrorism Risk: Challenges and Perspectives”, OECD, Terrorism Risk Insurance in OECD Countries, Paris, OECD Publishing 2005, pp. 107-148.

H. Kunreuther \& M. Pauly, "Rules Rather Than Discretion: Lessons From Hurricane Katrina”, 33 Journal of Risk and Uncertainty 2006, pp. 101-116.

H. Kunreuther, R. Hogarth \& J. Mezaros, "Insurer Ambiguity and Market Failure”, 7 Journal of Risk and Uncertainty 1993, pp. 71-87. 
Larosière Report, The High-Level Group on Financial Supervision in the E.U. (Feb. 25, 2009).

R. MacMinn \& J. Garvin, "On Corporate Insurance”, in G. Dionne (Ed.), Handbook of Insurance, Boston, Kluwer Academic Publishers 2000, pp. 541-564.

A. Monti, "Environmental Risk: A Comparative Law and Economics Approach to Liability and Insurance", 1 European Review of Private Law 2001, pp. 51-79.

O. Moreteau, "Policing the Compensation of Victims of Catastrophes: Combining Solidarity and Self-responsibility", in W.H. van Boom \& M. Faure (eds.), Shifts in Compensation Between Private and Public Systems, Vienna, Springer 2007, pp. 199-218.

O. Moreteau, M. Cannarsa \& F. Lafay, "France", in M. Faure \& T. Hartlief (eds.), Financial Compensation for Victims of Catastrophes. A Comparative Legal Approach, Vienna, Springer 2006, pp. 81-118.

H. Pack, "Due Diligence", in G. Picot (Ed.), Handbook of Mergers and Acquisitions, Basingstoke, Macmillan 2002, pp. 153-183.

G. Priest, "The Government, the Market and the Problem of Catastrophic Loss”, 12 Journal of Risk and Uncertainty 1996, pp. 219-237.

S.L. Schwarcz, "Systemic Risk”, 97 Georgia Law Journal 2008, pp. 193249.

R. Schwarze \& G. Wagner, "In the Aftermath of Dresden. New Directions in German Flood Insurance", 29 Geneva Papers on Risk and Insurance 2004, pp. 154-168.

S. Shavell, "On Moral Hazard and Insurance”, 93 Quarterly Journal of Economics 1979, pp. 541-562.

J.R. Skees \& B.J. Barnett, "Conceptual and Practical Considerations for Sharing Catastrophic/Systemic Risks”, 21 Review of Agricultural Economics 1999, pp. 424-441.

P. Slovic, B. Fischoff, S. Liechtenstein, B. Corrigan \& B. Combs, "Preference for Insuring Against Probable Small Losses: Insurance Implications", in P. Slovic (Ed.), The Perception of Risk, London, Earthscan 2000, pp. 51-72.

J.M. Stone, "A Theory of Capacity and the Insurance of Catastrophe Risks (Part I)”, 40 Journal of Risk and Insurance 1973, pp. 231-243.

M.J. Von der Schulenburg-Graf, "Comment During the Discussion of a Meeting on Insurability", in Der Umgang mit den Risiken im Grenzbereich der Versicherbarkeit. Dokumentation über ein Symposium 
am 18.-20. Oktober 2001 in Schloss Marbach, Böhningen, Karlsruhe, Verlag Versicherungswirtschaft 2002, pp. 9-10.

Verordnung über die Erhebung der Beiträge zum

Restrukturierungsfonds für Kreditinstitute, RestrukturierungsfondsVerordnung RstruktFV 2011.

\section{Noten}

1 For an extensive report on the financial crisis since 2007 see, e.g. Acharya et al. 2009. The authors discuss the perils of bailing out banks in an ad hoc manner as well as they propose several instruments to prevent financial crises.

2 Faure \& Hartlief 2006.

3 For a more detailed discussion of the here presented proposal, see Faure \& Heine 2011, 2012, 2013, where inter alia the problem of European state aid control is discussed and the possibility of insuring the enterprise risk becomes more rigorously addressed.

4 E.g. Anabtawi \& Schwarcz 2010; Schwarcz 2008.

5 MacMinn \& Garvin 2000.

6 Faure \& Hartlief 2003, pp. 84-85.

7 Monti 2001.

8 Acharya et al. 2009.

9 Danielsson 2003; Danielsson \& Shin 2002; Dowd 2009.

10 Arrow 1963.

$11 C f$. Akerlof 1970.

12 See on capacity as a condition for insurability of systemic risks Faure \& Hartlief 2003, pp. 88-106. For an in-depth analysis of the capacity problem see also Stone 1973.

13 Kunreuther et al. 1993.

14 See Shavell 1979.

15 Von der Schulenburg-Graf 2002.

16 Crocker \& Snow 2000.

17 Faure \& Hartlief 2003, pp. 88-90. 
19 Epstein 1996.

20 Priest 1996.

21 Kaplow 1991.

22 Skees \& Barnett 1999.

23 Kunreuther 1968.

24 See Harrington 2000; Kunreuther 1996; Schwarze \& Wagner 2004.

25 Epstein 1996; see also Kunreuther \& Pauly 2006.

26 Kunreuther \& Michel-Kerjan 2004.

27 Kunreuther \& Michel-Kerjan 2005.

28 Schwarze \& Wagner 2004.

29 Pack 2002.

30 The cases of Enron and Parmalat have clearly pointed to the deficient role of accounting firms. In addition, the New York attorney general Andrew Cuomo sued Ernst \& Young, charging the accounting firm of helping Lehman Brothers, its client, to 'engage in a massive accounting fraud' by misleading investors about the investment bank's financial status (21 December 2010, Supreme Court of the United States, County of New York).

31 Kunreuther \& Michel-Kerjan 2004.

32 Kunreuther \& Michel-Kerjan 2004.

33 Moreteau 2007; Moreteau et al. 2006.

34 Slovic et al. 2000.

35 Faure 2007.

36 See Verordnung über die Erhebung der Beiträge zum Restrukturierungsfond für Kreditinstitute 2011. 